\title{
PENENTUAN PENERIMAAN BANTUAN PANGAN NONTUNAI DENGAN METODE SIMPLE ADDITIVE WEIGHTED
}

\section{DETERMINATION OF ACCEPTANCE OF NON-CASH FOOD ASSISTANCE WITH THE SIMPLE ADDITIVE WEIGHTED METHOD}

\author{
Mochzen Gito Resmi ${ }^{1}$, Muhammad Rafi Muttaqin ${ }^{2}$, Meriska Defriani ${ }^{3}$ \\ Teknik Informatika, STT Wastukancana \\ mochzen@stt-wastukancana.ac.id
}

\begin{abstract}
Non-Cash Food Assistance / Bantuan Pangan Non Tunai (BPNT) is food aid provided by the government to the poor in Indonesia. This assistance aims to reduce the burden of expenditure and provide better nutritional intake to the poor on target and on time. Based on these, Dinas Sosial of Purwakarta Regency, especially Balinsos Sector, must be able to determine the beneficiary family / Keluarga Penerima Manfaat $(K P M)$ participants in accordance with the regulations set by the President regarding the distribution of non-cash social assistance. In conducting the selection process for Beneficiary Family (KPM) participants, criteria are needed to select candidate participants who will be selected as Beneficiary Families (KPM) for Non-Cash Food Assistance. This study uses the Simple Additive Weighted (SAW) method and the Waterfall system development method. With the establishment of a Decision Support System to determine Beneficiary Family (KPM) participants for Non-Cash Food Assistance, Dinas Sosial of Purwakarta Regency will find it easier to provide alternative decisions on which participants are more entitled to receive.
\end{abstract}

Keywords: Simple Additive Weighted, Decision Support System, Non-cash Food Assistance, Waterfall.

\begin{abstract}
ABSTRAK
Bantuan Pangan Non Tunai (BPNT) merupakan bantuan pangan yang diberikan oleh pemerintah kepada masyarakat miskin yang ada di Indonesia. Bantuan tersebut bertujuan untuk mengurangi beban pengeluaran dan memberikan asupan nutrisi yang lebih baik kepada masyarakat miskin secara tepat sasaran dan tepat waktu. Berdasarkan hal tersebut, Dinas Sosial Kabupaten Purwakarta khususnya Bidang Balinsos harus mampu menentukan peserta Keluarga Penerima Manfaat (KPM) sesuai dengan peraturan yang telah ditentukan oleh Presiden tentang penyaluran bantuan sosial non tunai. Dalam melakukan proses pemilihan peserta Keluarga Penerima Manfaat (KPM) diperlukan kriteria-kriteria untuk memilih calon peserta yang akan terpilih menjadi Keluarga Penerima Manfaat (KPM) Bantuan Pangan Non Tunai. Penelitian ini mengunakan metode Simple Additive Weighted (SAW) dan metode pengembangan sistem Waterfall. Dengan dibuatnya Sistem Pendukung Keputusan untuk menentukan peserta Keluarga Penerima Manfaat (KPM) Bantuan Pangan Non Tunai, Dinas Sosial Kabupaten Purwakarta lebih mudah dalam memberikan alternatif keputusan siapa peserta yang lebih berhak menerima. Hasil alternatif keputusan dilengkapi dengan nilai prioritas yang mengacu pada kriteria-kriteria pengambilan keputusan yang telah ditetapkan.
\end{abstract}

Kata Kunci: Simple Additive Weighted, Sistem Pendukung Keputusan, Bantuan Pangan Non Tunai, Waterfall.

\section{PENDAHULUAN}

Bantuan Pangan Non Tunai (BPNT) merupakan bantuan pangan yang diberikan oleh pemerintah kepada masyarakat miskin yang ada di Indonesia (Husaini \& Purwidayanta, 2019). Bantuan tersebut bertujuan untuk mengurangi beban pengeluaran dan memberikan asupan nutrisi yang lebih baik kepada masyarakat miskin secara tepat sasaran dan tepat waktu. Sistem baru penyaluran bantuan pangan ini diatur dalam Peraturan Presiden Nomor 63 Tahun 2017 tentang penyaluran bantuan sosial secara non tunai (Yulianti \& Farina, 2020). Bantuan sosial non tunai diberikan dalam rangka penanggulangan kemiskinan yang terdiri 
dari perlindungan, jaminan, pemberdayaan, dan rehabilitasi sosial, serta pelayanan dasar.

Sistem Pendukung Keputusan atau biasa dikenal dengan SPK sangatlah berguna untuk perusahan atau instansi. karena pesatnya perkembangan teknologi di dunia ini, maka untuk mengimbangi perkembangannya Dinas Sosial Kab. Purwakarta perlu menggunakan sistem untuk mempermudah kinerja. Banyaknya masyarakat kurang mampu di Kabupaten Purwakarta, maka Dinas Sosial Kabupaten Purwakarta khususnya Bidang Balinsos harus bisa menentukan peserta Keluarga Penerima Manfaat (KPM) sesuai dengan peraturan yang telah ditentukan oleh Presiden tentang penyaluran bantuan sosial non tunai, dalam melakukan proses pemilihan peserta Keluarga Penerima Manfaat (KPM) diperlukan kriteria-kriteria untuk memilih calon peserta yang akan terpilih menjadi Keluarga Penerima Manfaat (KPM) Bantuan Pangan Non Tunai (Riyansuni \& Devitra, 2020).

Berdasarkan permasalahan tersebut maka, Dinas Sosial Kabupaten Purwakarta membutuhkan sebuah Sistem Pendukung Keputusan untuk memberikan pilihan alternatif dan mempermudah dalam menetukan calon peserta Keluarga Penerima Manfaat (KPM) dengan metode Simple Additive Weighted (SAW). Dengan dibuatnya Sistem Pendukung Keputusan menentukan peserta Keluarga Penerima Manfaat (KPM) Bantuan Pangan Non Tunai di Dinas Sosial Kabupaten Purwakarta, memberikan kemudahan dalam memberikan alternatif keputusan dalam memilih peserta penerima Bantuan Pangan Non Tunai (BPNT) dilengkapi nilai prioritas dengan mengacu kepada kriteria-kriteria pengambilan keputusan yang telah ditetapkan.

\section{METODE}

Sistem Pendukung Keputusan dapat diartikan sebagai suatu program komputer yang menyediakan informasi di dalam aplikasi yang dibuat oleh suatu model analisi keputusan dan akses ke database, dimana hal ini dimuat untuk mendukung suatu keputusan (decision maker) dalam mengambil keputusan secara efektif baik dalam kondisi yang kompleks dan tidak terstruktur (Wolo, dkk., 2019). Sistem pendukung keputusan adalah proses pengambilan keputusan dimana komputer digunakan untuk membantu pengambil keputusan dengan menggunakan beberapa data dan model tertentu untuk menyelesaikan masalah yang tidak terstruktur(Fitriana, dkk., 2015). Keberadaan sistem pendukung keputusan pada perusahaan atau organisasi bukan untuk menggantikan tugas-tugas pengambil keputusan, namun untuk membantu menentukan pilihan dalam pengambilan keputusan. Sistem pendukung keputusan ini mengolah data menjadi informasi yang dapat digunakan untuk mengambil keputusan dari masalah-masalah semiterstruktur(Qiyamullailiy, dkk., 2020). Dalam implementasnya, hasil keputusan dari sistem bukanlah hal yang menjadi tolak ukur, pengambilan keputusan tetap berada pada pihak pengambil keputusan. Sistem hanya menghasilkan keluaran yang merupakan hasil kalkulasi datadata sebagaimana pertimbangan pihak pengambil keputusan sehingga pihak pengambil keputusan dapat lebih mudah dalam menentukan keputusan(Riandari, dkk., 2017).

Sistem Pendukung Keputusan terdiri dari tiga komponen yaitu :

Database

Sistem database merupakan kumpulan dari semua data bisnis yang dimiliki oleh perusahan, baik yang berasal dari transaksi sehari-hari, maupun data master. Untuk keperluan 
sistem pendukung keputusan, diperlukan data yang relevan dengan permasalahan yang hendak dipecahkan melalui simulasi(Mubarok, dkk., 2019).

Model Base

Suatu model yang merepresentasikan permasalahan ke dalam format kuantitatif (model matematika) sebagai dasar simulasi atau pengambilan keputusan, termasuk didalamnya tujuan permasalahan (obyektif), komponen-komponen terkait, dan batasan-batsan yang ada (constraints)(Hidayat, dkk., 2017).

Software System

Software system merupakan gabungan antara database dan model base. Model yang telah direpresentasikan sebelumnya kemudian diimplementasikan ke dalam computer(Yulianti \& Juwita, 2016).

Simple Additive Weighted (SAW)

Metode Simple Additive Weighted (SAW) juga dikenal dengan istilah metode penjumlahan terbobot. Metode SAW merupakan metode yang banyak digunakan dalam sistem pendukung keputusan yang memiliki banyak atribut. Konsep dasar dari metode ini adalah mencari penjumlahan terbobot dari rating kinerja pada semua atribut(Hidayat, Muslihudin, \& Utami, 2020). Metode SAW membutuhkan proses normalisasi matriks keputusan (X) ke suatu skala yang dapat diperbandingkan dengan semua rating alternative yang ada(Susanto \& Eriana, n.d.). Kriteria penilaian dalam metode ini dapat ditentukan sendiri sesuai dengan kebutuhan perusahaan(Sarwono, 2019). Berikut ini adalah langkah-langkah penyelesaian dalam metode SAW:

1. Menentukan kriteria-kriteria yang dijadikan acuan dalam pendukung keputusan.

2. Menentukan rating kecocokan setiap alternatif pada setiap kriteria. Rumus perhitungan rating kerja ternormalisasi dapat dilihat pada persamaan 1 .

3. Membuat matriks keputusan berdasarkan kriteria.

4. Melakukan normalisasi matriks berdasarkan persamaan yang disesuaikan dengan jenis atribut (atribut keuntungan maupun atribut biaya) sehingga diperoleh matriks ternormalisas.

5. Hasil akhir diperoleh dari proses perangkingan yaitu penjumlahan dari perkalian matriks ternormalisasi dengan vektor bobot sehingga diperoleh nilai terbesar yang dipilih sebagai alternatis terbaik sebagi solusi. Nilai akhir alternatif dapat dihitung dengan menggunakan rumus pada persamaan 2 .

$R_{i j}=$
$\left\{\begin{array}{l}\frac{X_{i j}}{\max x_{i j}}, \text { jika } j \text { adalah atribut keuntungan (benefit) } \\ \frac{\min X_{i j}}{X_{i j}}, \text { jika j adalah atribut biaya (cost) }\end{array}\right.$

Dengan $\mathrm{R}_{\mathrm{ij}}$ adalah Rating kinerja ternormalisasi, Max $_{\mathrm{ij}}$ adalah nilai maksimum dari setiap baris dan kolom, Min $_{i j}$ adalah nilai minimum dari setiap baris dan kolom, dan Xij adalah baris dan kolom dari matriks(Astradanta, dkk., 2016).

$$
V_{i}=\sum_{j=1}^{n} W_{j} R_{i j}
$$

Dengan $\mathrm{V}_{\mathrm{i}}$ adalah nilai akhir dari alternatif, $\mathrm{W}_{\mathrm{i}}$ adalah bobot yang telah ditentukan, dan $\mathrm{R}_{\mathrm{ij}}$ adalah normalisasi matriks.

\section{Model Waterfall}

Model waterfall adalah model
klasik yang
sistematis(Tristianto, 2018), yaitu
berurutan dalam membangun software.
Nama model ini sebenarnya adalah
"Linear Sequential Model". Model ini


sering disebut juga dengan "classic life cycle" atau metode waterfall. Model ini termasuk ke dalam model generic pada rekayasa perangkat lunak(Rifai \& Yuniar, 2019).

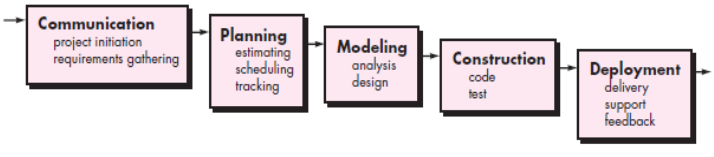

Gambar 1. Model Waterfall

Berikut ini adalah penjelasan setiap tahapan dalam metode waterfall:

1. Communication (Project Initiation \& Requirements Gathering)

Tahap ini bertujuan untuk berkomunikasi dengan costumer demi memahami dan mencapai tujuan yang ingin dicapai. Seperti menganalisis permasalahan, mengumpulkan data yang diperlukan serta dapat mencari tambahan data dari jurnal, artikel dan internet.

2. Planning (Estimating, Scheduling, Tracking).

Tahap ini merupakan tahap perencanaan yang menjelaskan estimasi tugas-tugas teknis yang akan dilaksanakan, sumber daya yang diperlukan, penjadwalan kerja dan tracking proses pengerjaan sistem.

3. Modelling (Analysis \& Design)

Tahap ini merupakan kegiatan perancangan dan pemodelan arsitektur sistem, dan tampilan interface. Tujuannya untuk lebih memahami gambaran besar dari apa yang akan dikerjakan.

\section{Construction (Code \& Test)}

Tahap ini merupakan kegiatan proses penerjemahan bentuk desain menjadi kode atau bentuk/bahasa yang dapat dibaca oleh mesin. Setelah pengkodean selesai dilakukan pengujian terhadap sistem.

\section{Deployment}

Tahap ini merupakan tahapan implementasi software dari penulis ke Dinas Sosial Kab.Purwakarta, penulis menjelaskan aplikasi yang dibuat kepada admin dan kepala bidang Balinsos.

\section{HASIL DAN PEMBAHASAN}

Pada bagian ini dibahas mengenai hasil penelitian tentang sistem pendukung keputusan untuk menentukan peserta Keluarga Penerima Manfaat (KPM) Bantuan Pangan Non Tunai di Dinas Sosial Kabupaten Purwakarta. Tahap awal yang dilakukan dalam penelitian ini adalah communication dimana dalam prosesnya dilakukan project initiation dan requirement gathering.

Permasalahan dianalisis dengan menggunakan metode wawancara secara langsung kepada kepala bidang Balinsos di Dinas Sosial Kabupaten Purwakarta. Kesimpulan permasalahan yang didapatkan adalah jumlah KPM yang ada di Kabupaten Purwakarta sebanyak 46 ribu jiwa atau 4,7\% dari jumlah penduduk Kabupaten Purwakarta namun yang memenuhi kriteria setiap desa atau kelurahan hanya berkisar 200 sampai 2000 KPM. Oleh karena itu, perlu adanya sebuah sistem yang mampu membantu untuk mengambil keputusan dalam memilih peserta KPM yang telah memenuhi kriteria di Dinas Sosial Kabupaten Purwakarta. Sistem penentuan peserta Keluarga Penerima Manfaat (KPM) Bantuan Pangan Non Tunai di Dinas Sosial Kabupaten Purwakarta yang saat ini sedang berjalan dapat dilihat pada gambar 2, sementara sistem yang diusulkan dapat dilihat pada gambar 3.

Kriteria penentuan peserta KPM terdiri dari beberapa aspek yang telah ditetapkan sebagai acuan oleh bagian bidang Balinsos di Dinas Sosial Kabupaten Purwakarta. Kriteria tersebut adalah usia, pekerjaan, penghasilan, status perkawinan, jumlah tanggungan, dan status rumah. Seluruh kriteria yang 
digunakan merupakan atribut benefit atau keuntungan. Usia yang termasuk dalam kriteria adalah mulai dari 30 tahun sampai 65 tahun ke atas. Pekerjaan yang termasuk dalam kriteria adalah pekerja serabutan yang penghasilannya di bawah dan tidak menentu tiap bulannya. Penghasilan yang termasuk dalam kriteria adalah penghasilan yang tiap bulanya di bawah 2juta dan tidak menentu penghasilannya. Status Perkawinan menunjukkan siapa yang menjadi kepala keluarga siapa, jika status perkawinan janda maka nilai yang didapat akan lebih besar. Jumlah tanggungan adalah salah satu kriteria yang sangat penting karena makin banyak tanggungan keluarga makin banyak kebutuhan yang harus dipenuhi dan semakin berhak menerima bantuan. Status rumah juga merupakan kriteria yang sangat menentukan siapa yang berhak menerima bantuan.

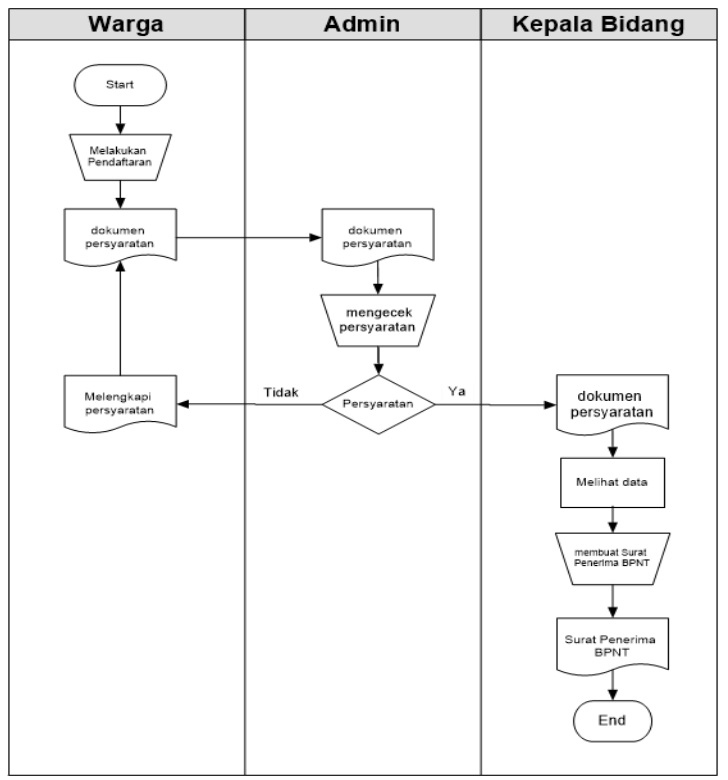

Gambar 2. Sistem Berjalan Penentuan Peserta Keluarga Penerima Manfaat (KPM)

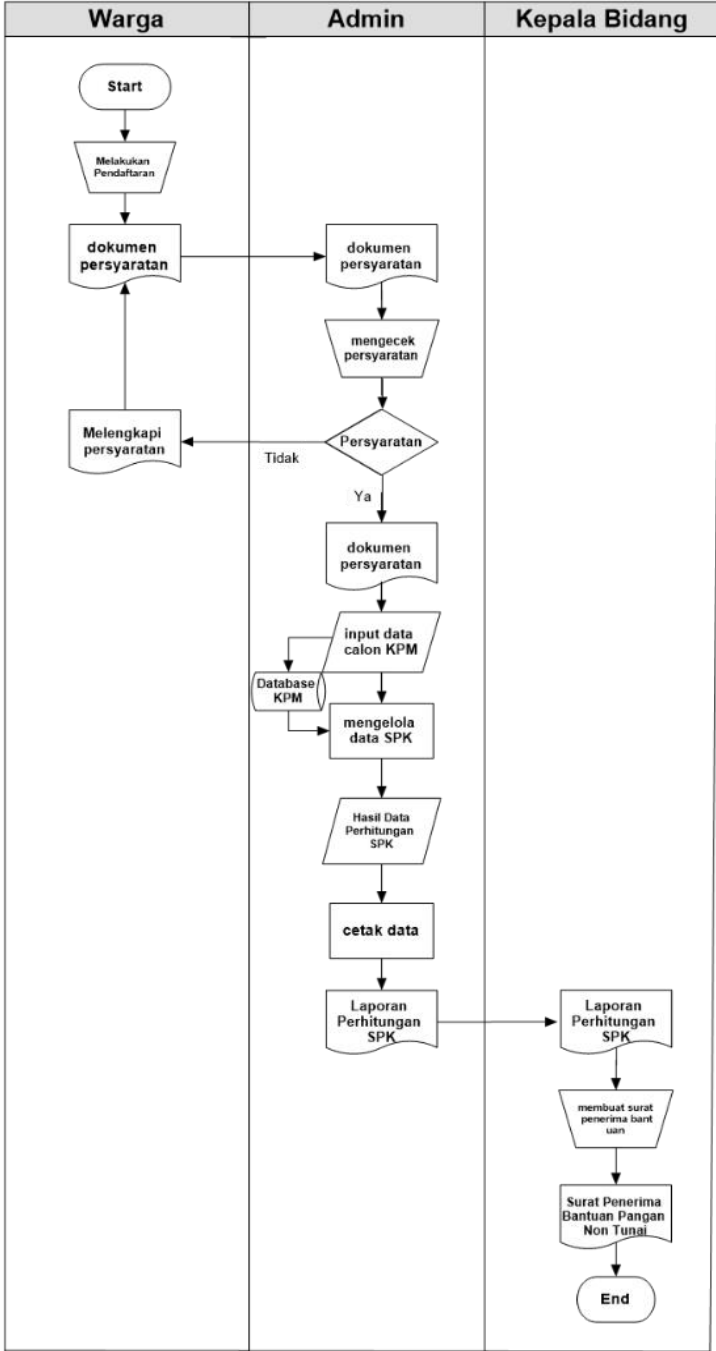

Gambar 3. Sistem Usulan Penentuan Peserta Keluarga Penerima Manfaat (KPM)

Kriteria yang telah ditentukan kemudian dikodekan untuk proses perhitungan nantinya. Pengkodean setiap kriteria tersebut dapat dilihat pada Tabel 1.

Tabel 1. Pengkodean Kriteria

\begin{tabular}{ccc}
\hline Kode & Nama Kriteria & $\begin{array}{c}\text { Presentasi } \\
\text { Bobot }\end{array}$ \\
\hline C1 & Usia (benefit) & $20 \%$ \\
\hline C2 & Pekerjaan (benefit) & $15 \%$ \\
\hline C3 & Penghasilan (cost) & $25 \%$ \\
\hline C4 & $\begin{array}{c}\text { Status Perkawinan } \\
\text { (benefit) }\end{array}$ & $10 \%$ \\
\hline C5 & $\begin{array}{c}\text { Jumlah Tanggungan } \\
\text { (benefit) }\end{array}$ & $20 \%$ \\
\hline C6 & $\begin{array}{c}\text { Status Rumah } \\
\text { (benefit) }\end{array}$ & $10 \%$ \\
\hline
\end{tabular}


Pada bagian ini akan dijelaskan contoh penentuan Peserta Keluarga Penerima Manfaat (KPM). Contoh data yang diguankan dapat dilihat pada Table 2.

Tabel 2. Nilai Kriteria

\begin{tabular}{ccccccc}
\hline \multirow{2}{*}{ ID } & \multicolumn{7}{c}{ ID Kriteria } \\
\cline { 2 - 7 } Alternatif & C & C & C & C & C & C \\
& 1 & 2 & 3 & 4 & 5 & 6 \\
\hline A1 & 5 & 5 & 4 & 1 & 4 & 3 \\
\hline A2 & 2 & 3 & 3 & 5 & 2 & 2 \\
\hline A3 & 3 & 2 & 3 & 2 & 3 & 3 \\
\hline
\end{tabular}

Nilai yang terdapat pada data Tabel 2 kemudian dinormalisasi sehingga menghasilkan matriks $\mathrm{R}$ di bawah ini.

$R=\left[\begin{array}{llllll}1,00 & 1,00 & 0,75 & 0,20 & 1,00 & 1,00 \\ 0,40 & 0,60 & 1,00 & 1,00 & 0,50 & 0,67 \\ 0,60 & 0,40 & 1,00 & 0,20 & 0,75 & 1,00\end{array}\right]$

Berdasarkan hasil perhitungan perangkingan, yaitu perkalian antara bobot kriteria dengan matriks $\mathrm{R}$, didapatkan jumlah nilai dari masingmasing alternatif yang dapat dilihat pada Table 3.

Tabel 3. Jumlah Nilai Setiap Alternatif

\begin{tabular}{|c|c|c|}
\hline No. & Alternatif & Jumlah Nilai \\
\hline 11 & A1 & 0,86 \\
\hline 22 & A2 & 0,68 \\
\hline 33 & A3 & 0,70 \\
\hline
\end{tabular}
dapat dilihat pada Table 3, dapat disimpulkan bahwa urutan rekomendasi alternatif untuk penentuan Peserta Keluarga Penerima Manfaat (KPM) adalah A1, A3, dan A2.

\section{SIMPULAN}

Bedasarkan hasil Sistem Pendukung Keputusan menentukan peserta Keluarga Penerima Manfaat (KPM) Bantuan Pangan Non Tunai di Dinas Sosial Kabupaten Purwakarta alternatif A1 mendapatkan nilai tertinggi dengan nilai 0,86 , A3 dengan nilai 0,70 dan A2 dengan nilai 0,68 , sehingga alternatif A1 lebih direkomendasikan untuk menjadi peserta KPM. Sistem pendukung keputusan yang telah dibuat dapat mempermudah dalam memberikan alternatif keputusan penentuan peserta penerima Bantuan Pangan Non Tunai (BPNT) dimana hasil perhitungannya dilengkapi nilai prioritas dengan mengacu kepada kriteria-kriteria pengambilan keputusan yang telah ditetapkan. Dengan adanya sistem ini bantuan dapat diberikan lebih sesuai dengan sasaran.

\section{DAFTAR PUSTAKA}

Astradanta, M., Wirawan, I. M. A., Kom, S., \& Arthana, I. K. R. (2016). Pengembangan Sistem Pendukung Keputusan Pemilihan Tempat Kuliner dengan Metode AHP dan SAW (Studi Kasus: Kecamatan Buleleng). KARMAPATI

(Kumpulan Artikel Mahasiswa Pendidikan Teknik Informatika), 5(2), 288-298.

Fitriana, A. N., Harliana, H., \& Handaru, H. (2015). Sistem pendukung keputusan untuk menentukan prestasi akademik siswa dengan metode TOPSIS. Creative Information Technology Journal, 2(2), 153-164.

Hidayat, A., Muslihudin, M., \& Utami, I. T. (2017). Sistem Pendukung Keputusan Menentukan Lokasi Cafe Baru Suncafe Sebagai Destinasi Wisata Kuliner Di Kabupaten Pringsewu Menggunakan Metode Simple Additive Weighting (SAW). Jurnal TAM (Technology Acceptance Model), 6, 71-79.

Husaini, R. R. N., \& Purwidayanta, S. (2019). Sistem Pendukung Keputusan Seleksi Penerima Bantuan Pangan Non Tunai Dengan Metode Simple Addictive Weighting (SAW). Jurnal 
Manajemen dan Teknik Informatika (JUMANTAKA), 2(1).

Mubarok, A., Suherman, H. D., Ramdhani, Y., \& Topiq, S. (2019). Sistem Pendukung Keputusan Kelayakan Pemberian Kredit Dengan Metode TOPSIS. Jurnal Informatika, 6(1), 37-46.

Qiyamullailiy, A., Nandasari, S., \& Amrozi, Y. (2020). Perbandingan Penggunaan Metode SAW dan AHP untuk Sistem Pendukung Keputusan Penerimaan Karyawan Baru. Teknika: Engineering and Sains Journal, 4(1), 7-12.

Riandari, F., Hasugian, P. M., \& Taufik, I. (2017). Sistem Pendukung Keputusan Menggunakan Metode Topsis Dalam Memilih Kepala Departemen Pada Kantor Balai Wilayah Sungai Sumatera II Medan. Journal of Informatic Pelita Nusantara, 2(1).

Rifai, A., \& Yuniar, Y. P. (2019).

Penerapan Metode Waterfall Dalam Perancangan Sistem Informasi Ujian Pada SMK Indonesia Global Berbasis Web. Jurnal Khatulistiwa Informatika, 7(1).

Riyansuni, I., \& Devitra, J. (2020). Analisis Dan Perancangan Sistem Pendukung Keputusan Penerima Bantuan Pangan Non Tunai (BPNT) Dengan Simple Additive Weighting (SAW) Pada Dinas Sosial Kota Jambi. Jurnal Manajemen Sistem Informasi, 5(1), 151-163.

Sarwono, D. (2019). Sistem Pendukung Keputusan Penerima Program Subsidi RASTRA dengan Metode Simple Additive Weighting (SAW). Emitor: Jurnal Teknik Elektro, 20(1), 40-46.

Tristianto, C. (2018, July). Penggunaan metode waterfall untuk pengembangan sistem monitoring dan evaluasi pembangunan pedesaan. In ESIT (Vol. 12, No. 1, pp. 8-22).

Wolo, P., Paseng, A. S. M., \& Roberth, Y. W. (2019). Sistem Pendukung Keputusan Penentuan Penerimaan Raskin Menggunakan Metode Simple Additive Weighting (Studi Kasus Kelurahan Kota Uneng). Teknika, 8(1), 74-77.

Yulianti, E., \& Farina, M. (2020). Sistem Pendukung Keputusan Penerima Bantuan Pangan Non Tunai (Bpnt) Untuk Keluarga Miskin Menggunakan Metode Simple Multi Attribute Rating Technique (SMART). Jurnal Teknoif, 8(1), 713.

Yulianti, E., \& Juwita, F. (2016). Sistem pendukung keputusan pemilihan tempat kuliner di Kota Padang menggunakan Metode Perbandingan Eksponensial (MPE). Jurnal Teknoif, 4(2). 